\title{
Properties of a Polygalacturonase Produced by Acrocylindrium
}

\author{
By H. KIMURA, F. UCHINO AND S. MIZUSHIMA \\ Laboratory of Microbiology, Faculty of Agriculture, \\ Nagoya University, Nagoya, Japan
}

(Received 5 June 1972 ; revised 30 August 1972)

\begin{abstract}
SUMMARY
A polygalacturonase has been purified from the culture fluid of a strain of Acrocylindrium. The purified preparation was homogeneous when examined by ultracentrifugation. The hydrolysis of $\mathrm{di}$ - and trigalacturonic acids by the enzyme was undetectable. Tetragalacturonic acid was hydrolysed to tri- and monogalacturonic acids, while pentagalacturonic acid was hydrolysed to either tri- and digalacturonic acids or tetra- and monogalacturonic acids. The rate of hydrolysis of pentagalacturonic acid to tri- and digalacturonic acids was about four times as fast as that to tetra- and monogalacturonic acids. It was concluded that the enzyme can hydrolyse any glycosidic bond between the reducing end and the third galacturonic-acid unit from the non-reducing end of polygalacturonic acid. The manner of hydrolysis of polygalacturonic acid by the enzyme is different from that of any other polygalacturonase reported so far.
\end{abstract}

\section{INTRODUCTION}

One plant and many micro-organisms are known to produce enzymes that hydrolyse polygalacturonic acid. Such polygalacturonases have been classified into two groups. One group which hydrolyses internal bonds of polygalacturonic acid has been found from fungi (Mill \& Tuttobello, I96r; Endo, 1964a; Uchino, Kurono \& Doi, 1966; Koller \& Neukom, I969), from a bacterium (Nasuno \& Starr, I966), from a yeast (Patel \& Phaff, 1959) and from tomato (Patel \& Phaff, I960). According to Demain \& Phaff's (I957) definition, these enzymes are called endo-polygalacturonases. Another group, the exopolygalacturonases, hydrolyse only a terminal bond. Enzymes of this kind were studied by Endo (1964b) and (Mill I966a, 1966b).

In our laboratory, Uchino et al. (I966) found that a strain of Acrocylindrium produced a significant amount of polygalacturonase. The enzyme was crystallized and called endopolygalacturonase because it was not able to hydrolyse more than $50 \%$ of the glycosidic bonds in polygalacturonic acid. Recently we have studied the action of the enzyme on oligogalacturonic acids. The present paper reports the properties of the enzyme with special reference to substrate specificity.

\section{METHODS}

Organism and cultivation. The fungus used was a strain of Acrocylindrium, which was kindly supplied by the National Institute of Agricultural Sciences, Tokyo, Japan. The growth medium contained $(\mathrm{g} / \mathrm{IOO} \mathrm{ml})$ : pectin (Katayama Kagaku Co., Tokyo), 5; yeast extract (Oriental Yeast Co., Tokyo), 0.2; $\mathrm{NH}_{4} \mathrm{NO}_{3}, \mathrm{I} ; \mathrm{KH}_{2} \mathrm{PO}_{4}, 0.5 ; \mathrm{MgSO}_{4} \cdot 7 \mathrm{H}_{2} \mathrm{O}, 0.05 ; \mathrm{CaCl}_{2}$. $2 \mathrm{H}_{2} \mathrm{O}, 0 \cdot 0 \mathrm{r} ; \mathrm{pH} 5 \cdot 6$. Cultures were grown in $500 \mathrm{ml}$ flasks containing $100 \mathrm{ml}$ medium using a reciprocal shaker ( 136 strokes $/ \mathrm{min}$ ) at $30^{\circ} \mathrm{C}$ for $72 \mathrm{~h}$. 
Enzymatic assay. Polygalacturonase activity was measured either by determining aldehyde groups formed or by measuring the decrease in viscosity of polygalacturonic acid (PGA), a product from Sigma Chemical Co., St Louis, Missouri, U.S.A.

For measuring the rate of formation of aldehyde groups, I $\mathrm{ml}$ of suitably diluted enzyme solution was added to $5 \mathrm{ml}$ of $0.6 \%(\mathrm{w} / \mathrm{v})$ PGA solution in $0 . \mathrm{I}$ M-acetate buffer $\left(\mathrm{pH}_{4} \cdot \mathrm{I}\right)$ preincubated at $30^{\circ} \mathrm{C}$. The reaction mixture was incubated at $30{ }^{\circ} \mathrm{C}$. The amount of aldehyde formed was determined by the hypoiodite method of Jansen \& MacDonnell (I945). The sample was mixed with $\mathrm{I} \mathrm{ml}$ of $\mathrm{I} \mathrm{M}-\mathrm{Na}_{2} \mathrm{CO}_{3}$ in a glass-stoppered Erlenmeyer flask, to which was then added $5 \mathrm{ml}$ of $0.1 \mathrm{~N}$-iodine. The mixture was allowed to stand for $20 \mathrm{~min}$, and was then acidified with $2 \mathrm{ml}$ of $2 \mathrm{M}^{-} \mathrm{H}_{2} \mathrm{SO}_{4}$. The iodine remaining in the solution was titrated with $0.05 \mathrm{~N}-\mathrm{Na}_{2} \mathrm{~S}_{2} \mathrm{O}_{3}$. One unit of polygalacturonase activity (PG unit) was defined as the amount of enzyme which produces I micromol of aldehyde groups/min at $30{ }^{\circ} \mathrm{C}$. A semimicro hypoiodite method was used with $0.25 \%(\mathrm{w} / \mathrm{v})$ substrate (Patel \& Phaff, 1959).

Viscosity decrease was measured by the method of Roboz, Barratt \& Tatum (I952). The reaction conditions were exactly the same as those for the aldehyde-group assay. One viscometric unit (VR unit) was defined as the amount of enzyme which reduced the viscosity of PGA by $50 \%$ in $10 \mathrm{~min}$.

Protein was estimated by the method of Lowry, Rosebrough, Farr \& Randall (I95I), with egg albumin (Katayama Kagaku Co.) as reference protein.

Analysis of reaction products. Reaction mixtures were treated with Dowex $50\left(\mathrm{H}^{+}\right.$form), evaporated to dryness and dissolved in $0.5 \mathrm{ml}$ water. Samples were spotted on Toyo Roshi no. 5IA paper and developed by descending chromatography with a solvent system of butanol-acetic acid-water ( $4: 2: 3$, by vol.). Under these conditions, GA, $2 \mathrm{GA}, 3 \mathrm{GA}$ * and their oxidized derivatives (the terminal aldehyde group being oxidized) were separable on paper. Identification of products on paper was made as follows. Aldehyde groups were detected by spraying with alkaline silver nitrate reagent at room temperature (Preiss \& Ashwell, I963). Carboxylic groups were located by spraying with a mixed reagent of bromocresol green and bromophenol blue (Pásková \& Munk, 1960). For quantitative analysis of products, reaction mixtures treated as described above were applied to paper in streaks. Areas containing reaction products were eluted from the paper with $0.2 \%(\mathrm{w} / \mathrm{v})$ ammonium oxalate on a shaker and the eluate was condensed to $0.5 \mathrm{ml}$ by evaporation. Uronic acids were estimated by the carbazole method of Dische (I 947) with slight modification (Matsumura, I969). Galacturonic acid (Sigma Chemical Co.) was used as the standard. Aldehyde groups were determined by the micro hypoiodite method of Hatanaka (I967).

Preparation of oligogalacturonic acids and their oxidized derivatives. $\mathrm{Di}$ - and trigalacturonic acids were prepared as described by Phaff \& Luh (1952). Digalacturonic and trigalacturonic acids thus prepared had $-\mathrm{COOH} /-\mathrm{CHO}$ ratios of $\mathrm{I} \cdot 98$ and $3 \cdot 05$, respectively. Tetra- and pentagalacturonic acids were prepared according to the method of Hatanaka \& Ozawa (I966) and had $-\mathrm{COOH} /-\mathrm{CHO}$ ratios of 3.85 and 4.90 , respectively. Oxidized oligogalacturonic acids were prepared by the hypoiodite oxidation method of Patel \& Phaff (I959). The terminal aldehyde group is changed to a carboxyl group by this method. The oxidized substrates showed no reducing activity.

Procedures for purification of enzyme. The enzyme was purified by a method based on that reported by Uchino et al. (1966), as follows. After $72 \mathrm{~h}$ cultivation, mycelia were removed by centrifugation at $10000 \mathrm{~g}$ for $5 \mathrm{~min}$. To $10 \mathrm{l}$ of the culture fluid was added $\mathrm{I} \cdot 5$

* Abbreviations used: GA, monogalacturonic acid; $2 \mathrm{GA}$, digalacturonic acid; $3 \mathrm{GA}$, trigalacturonic acid; 4GA, tetragalacturonic acid; 5GA, pentagalacturonic acid; PGA, polygalacturonic acid. 


\section{Table I. Summary of purification of polygalacturonase}

\begin{tabular}{|c|c|c|c|c|c|}
\hline Step & $\begin{array}{l}\text { Volume } \\
\text { (ml) }\end{array}$ & $\begin{array}{l}\text { Protein } \\
\text { (mg) }\end{array}$ & $\begin{array}{c}\text { Total } \\
\text { enzyme } \\
\text { activity } \\
\text { (PG units) }\end{array}$ & $\begin{array}{c}\text { Specific } \\
\text { enzyme } \\
\text { activity } \\
\left(\frac{\text { PG units }}{\text { mg protein }}\right)\end{array}$ & $\begin{array}{l}\text { Yield } \\
(\%)\end{array}$ \\
\hline Culture filtrate & 10000 & 46700 & 5600 & 0.12 & 100 \\
\hline Acetone precipitate & 500 & 21840 & 4360 & 0.20 & 78 \\
\hline Duolite CS-Io I eluate & I 000 & 5600 & 2800 & 0.50 & 50 \\
\hline Starch zone electrophoresis & I0 & 606 & 728 & $\mathrm{I} \cdot 20$ & I3 \\
\hline
\end{tabular}

volume of acetone $\left(-20^{\circ} \mathrm{C}\right)$. The precipitate formed was collected by centrifugation at $10000 \mathrm{~g}$ for $10 \mathrm{~min}$, dissolved in $300 \mathrm{ml}$ of distilled water, and dialysed against distilled water for $72 \mathrm{~h}$ at room temperature with frequent changes of outer medium. The dialysed solution (about $500 \mathrm{ml}$ ) was then applied on to a column of Duolite CS-IOI $(60 \times 270 \mathrm{~mm})$ which had been equilibrated with $0.05 \mathrm{M}$-sodium acetate buffer $(\mathrm{pH} 4)$. The column was washed with $2800 \mathrm{ml}$ of $0.2 \mathrm{M}$-acetate buffer $\left(\mathrm{pH}^{\circ} \cdot \mathrm{O}\right)$ and then eluted with $0.4 \mathrm{M}$-acetate buffer $(\mathrm{pH} 6 \cdot 0)$ at a flow rate of $240 \mathrm{ml} / \mathrm{h}$. The fractions containing enzyme activity were pooled. To the solution was added $\mathrm{I} \cdot 5$ volume of cold acetone $\left(-20^{\circ} \mathrm{C}\right)$. The precipitate formed was recovered by centrifugation at $10000 \mathrm{~g}$ for Io $\mathrm{min}$, dissolved in distilled water and dialysed against distilled water. Ten $\mathrm{ml}$ of the dialysed preparation obtained from 101 of the culture fluid was mixed with $12 \mathrm{~g}$ of dried starch grain (Maruishi Pharmaceutical Co., Osaka, Japan) and applied on to a starch block for zone electrophoresis. Electrophoresis was carried out on a starch block $(15 \times 100 \times 400 \mathrm{~mm})$ in $0^{\circ} \mathrm{I} \mathrm{M}$-phosphate buffer $(\mathrm{pH} 7 \cdot 0)$ with $60 \mathrm{~mA}, 340 \mathrm{~V}$ for $24 \mathrm{~h}$. The block was cut into slices (10 mm thick) which were frozen once at $-20{ }^{\circ} \mathrm{C}$ and thawed. The protein was extracted with distilled water and those fractions which had enzyme activity were pooled, precipitated with $\mathrm{I} \cdot 5$ volume of acetone and dialysed against $\mathrm{O} \cdot \mathrm{I} \mathrm{M}$-acetate buffer $(\mathrm{pH} 4 \cdot \mathrm{I})$.

\section{Purity of enzyme}

\section{RESULTS}

From the results on starch zone electrophoresis, the fungus appeared to produce only one kind of extracellular polygalacturonase. Table I, giving the data on the purification procedure, shows that with a loss of $87 \%$ of the original activity a Io-fold increase in specific activity had been achieved. The purity of polygalacturonase was examined in a SPINCO model E analytical ultracentrifuge. The schlieren pattern of the preparation showed a single peak with a sedimentation coefficient $\left(s_{16}^{\mathrm{w}}\right)$ of 5.8 (Fig. I). The purity of the preparation was also examined on a CM-cellulose column chromatogram with a linear $\mathrm{pH}$ gradient from $5^{\circ} 0$ to $7^{\circ}$. As shown in Fig. 2, there was a good coincidence between the protein patterns and the activity patterns measured by using two different methods. The result strongly indicates that the enzyme preparation was homogeneous.

\section{Effect of $\mathrm{pH}$ and temperature on enzyme activity}

The effect of $\mathrm{pH}$ on the polygalacturonase activity was studied by means of the hypoiodite assay under the standard conditions except that $0 \cdot \mathrm{I}$ M-citric acid- $\mathrm{Na}_{2} \mathrm{HPO}_{4}$ buffers with various $\mathrm{pH}$ values were used. The optimum $\mathrm{pH}$ was found to be approximately $4 \cdot 2$. The enzyme showed no activity at $\mathrm{pH} 2$ and 6 . The effect of $\mathrm{pH}$ on the stability of the enzyme 


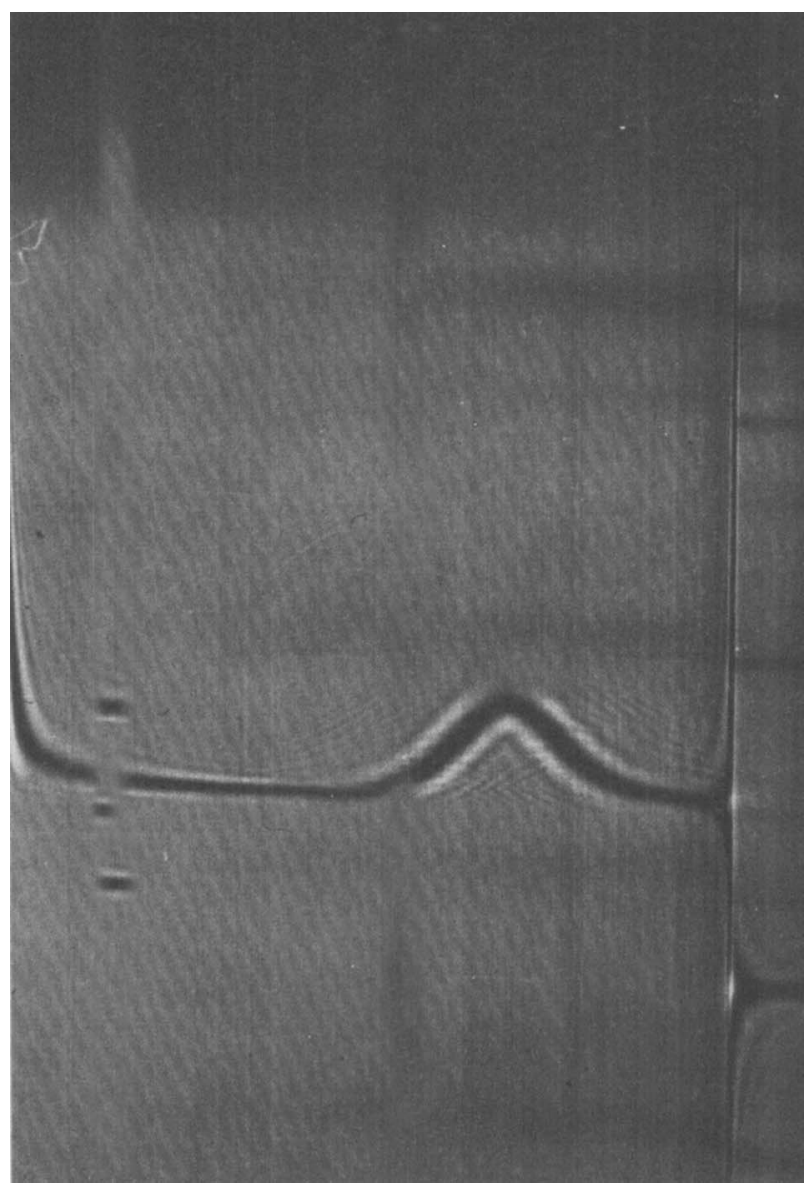

Fig. I. Ultracentrifugation of purified polygalacturonase. Protein solution $(5.0 \mathrm{mg} / \mathrm{ml}$ in $0.1 \mathrm{M}-$ acetate buffer, $\mathrm{pH} 4.5$ ) was centrifuged at $59780 \mathrm{rev}$./min with a Spinco model E analytical ultracentrifuge. Temperature was $16^{\circ} \mathrm{C}$ and photograph was taken with a bar angle of $60^{\circ}$ after $64 \mathrm{~min}$.

was also studied. The enzyme preparation was treated with either 0.1 M-citric acid$\mathrm{Na}_{2} \mathrm{HPO}_{4}\left(\mathrm{pH} 2 \cdot 0\right.$ to $8 \cdot 0$ ) or $0 \cdot \mathrm{I}$ M-tris- $\mathrm{HCl}$ buffer $\left(\mathrm{pH}_{7} \cdot 5\right.$ to $9 \cdot 0$ ) for $24 \mathrm{~h}$ at $30^{\circ} \mathrm{C}$. After this treatment the preparation was dialysed against acetate buffer $(\mathrm{pH} 4 \cdot \mathrm{I})$ and enzyme activity was measured using the standard assay condition. The enzyme was stable over a $\mathrm{pH}$ range from 2.5 to $7 \cdot 5$. Fifty per cent inactivation was observed at $\mathrm{pH} 9 \cdot 0$.

Fig. 3 shows the effect of heat on the stability of the enzyme. Without PGA the enzyme was stable up to $40{ }^{\circ} \mathrm{C}$, but lost more than $80 \%$ of its activity at $50{ }^{\circ} \mathrm{C}$. However, the enzyme retained more than $90 \%$ of its activity at $40{ }^{\circ} \mathrm{C}$ in the presence of PGA, a substrate of the enzyme. The result shows that the enzyme was protected by its substrate from heat inactivation.

\section{Effect of metal ions and chelating reagents on enzyme activity}

The following metal ions ( $\mathrm{I} \mathrm{mM}$ ) did not show any significant inhibitory effect on the enzyme activity under the conditions of the standard assay: $\mathrm{Li}^{+}, \mathrm{Na}^{+}, \mathrm{K}^{+}, \mathrm{Ag}^{+}, \mathrm{Mg}^{2+}$, 


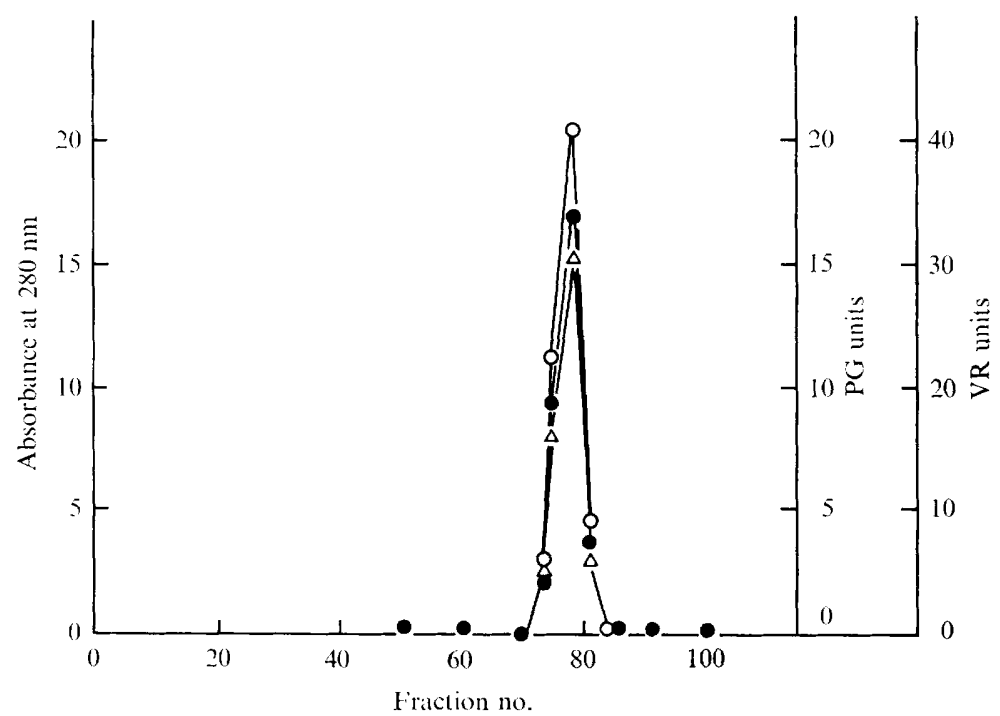

Fig. 2. Chromatogram of purified polygalacturonase on CM-cellulose column. The protein solution was adsorbed on to a CM-cellulose column (Brown Co., Berlin, New Hampshire, U.S.A., $0.6 \mathrm{~m}$-equiv. $/ \mathrm{g}, 22 \times 200 \mathrm{~mm}$ ) which had been equilibrated with $0.01 \mathrm{~m}$-sodium phosphate buffer $\left(\mathrm{pH} 5^{\circ}\right)$. The protein was eluted with a $0^{\circ} \mathrm{I}$ M-sodium phosphate buffer gradient $\left(\mathrm{pH} 5^{\circ} \mathrm{O}\right.$ to

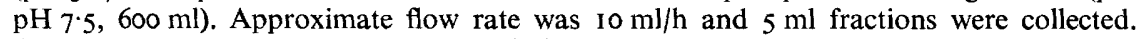
Absorbance at $280 \mathrm{~mm} ; \bigcirc-\bigcirc$, PG units $/ \mathrm{ml} ; \triangle-\triangle$, VR units $/ \mathrm{ml}$.

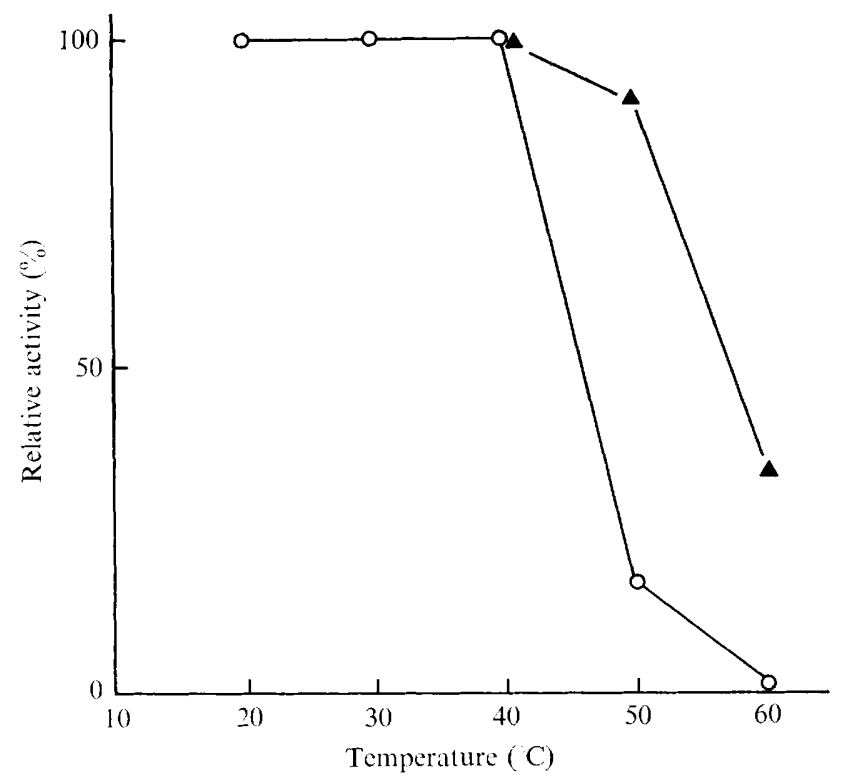

Fig. 3. Heat stability of polygalacturonase. The enzyme (3.8 PG units) dissolved in 0.1 M-acetate buffer $(\mathrm{pH} 4 . \mathrm{I})$ was heated for $5 \mathrm{~min}$ at the indicated temperatures with or without $0.5 \%(\mathrm{w} / \mathrm{v})$ PGA. Enzyme assay was made under the standard condition with the hypoiodite method. $\bigcirc-\bigcirc$, In the absence of PGA; $\boldsymbol{\Delta}-\boldsymbol{\Delta}$, in the presence of PGA. 


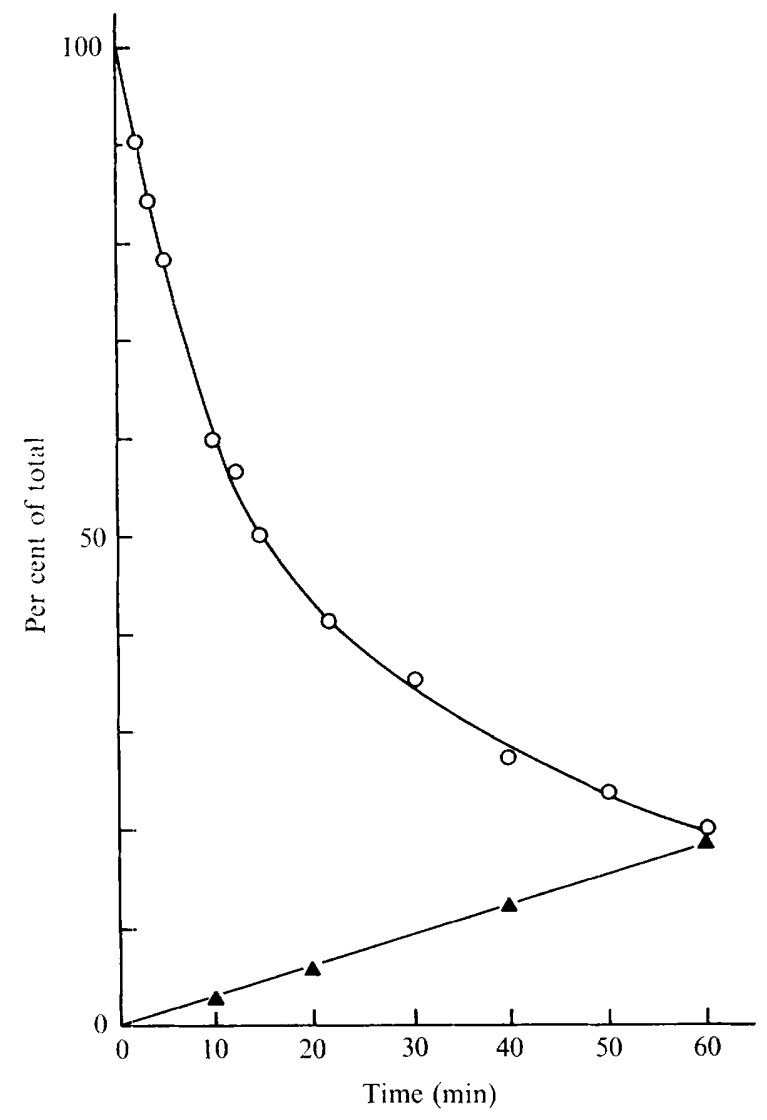

Fig. 4. Time course of hydrolysis of polygalacturonic acid by enzyme. The decrease of viscosity and the increase of aldehyde group were assayed under the standard conditions. $\mathbf{\Delta}-\mathbf{\Delta}$, Aldehyde group formed assayed by the hypoiodite method; $\mathrm{O}-\mathrm{O}$, viscosity decrease assayed by the viscometric method.

$\mathrm{Ca}^{2+}, \mathrm{Sr}^{2+}, \mathrm{Ba}^{2+}, \mathrm{Mn}^{2+}, \mathrm{Co}^{2+}, \mathrm{Ni}^{2+}, \mathrm{Pb}^{2+}, \mathrm{Al}^{3+}, \mathrm{Fe}^{3+}$ and $\mathrm{Sn}^{4+}$. The effect of chelating reagents on the enzyme activity was also studied. The following reagents (I $\mathrm{mM}$ ) showed no significant effect: iodoacetate, $N$-ethylmaleimide, $\alpha \alpha^{\prime}$-dipyridyl and 8 -hydroxyquinoline.

\section{Substrate specificity of enzyme action}

The enzyme showed no activity towards pectin. A comparison was made of the viscosity decrease and the increase in the hydrolysis of PGA. As shown in Fig. 4, 50\% loss in viscosity was observed when $5 \%$ of the glycosidic bonds had been hydrolysed. The large decrease in viscosity accompanied by a small increase in the amount of aldehyde group indicates that the enzyme hydrolyses internal bonds of PGA. The reaction products were quantitatively analysed on paper chromatograms. As shown in Fig. 5, GA, 2GA and 3GA were the main end products. The amount of aldehyde group formed which is estimated from the formation of these oligomers showed good agreement with the amount of glycosidic bond hydrolysed (Fig. 5). Pentagalacturonic acid, which is formed in the early period of the incubation, quickly disappeared accompanied by an increase of smaller oligomers. The disappearance of $4 \mathrm{GA}$ was accompanied by the formation of $3 \mathrm{GA}$ and $\mathrm{GA}$ but not $2 \mathrm{GA}$, suggesting the cleavage of $4 \mathrm{GA}$ to $3 \mathrm{GA}$ and $\mathrm{GA}$. 


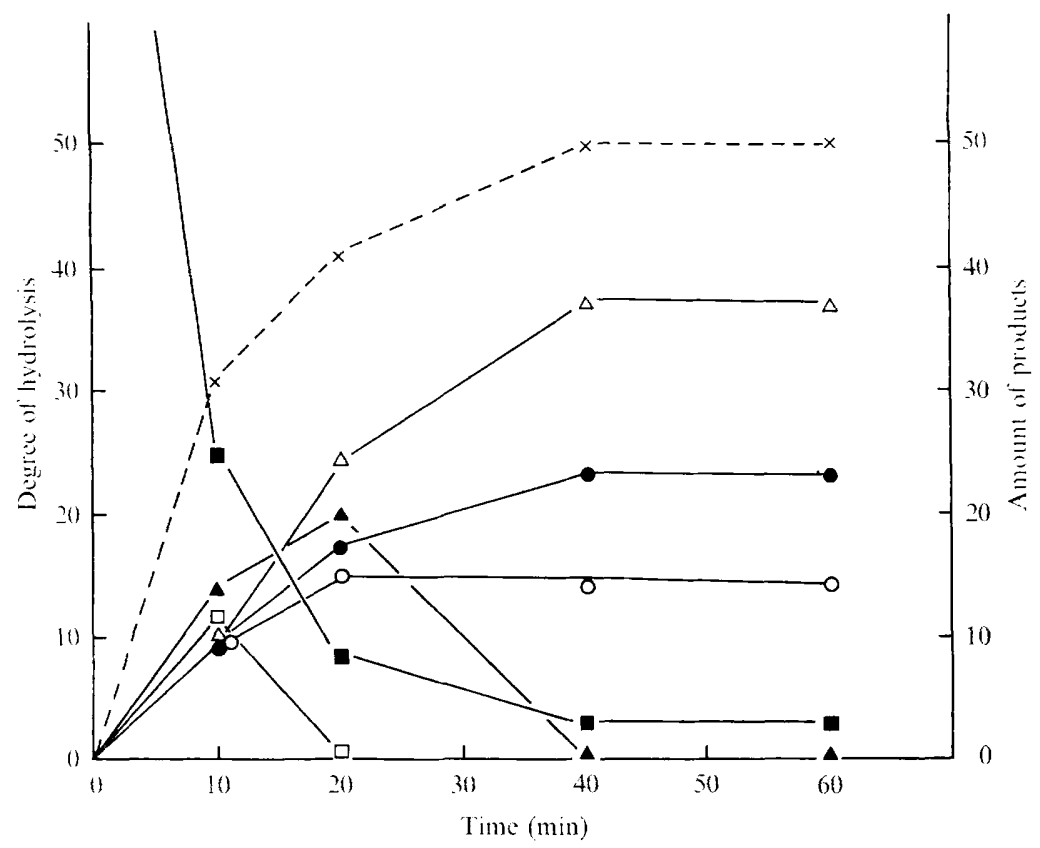

Fig. 5. Time course of hydrolysis of polygalacturonic acid. Incubation was under the standard condition. The amount of each product was determined with carbazole reagent after chromatographic separation on paper as described under Methods. The degree of hydrolysis of PGA was estimated by the hypoiodite method. $\times---\times$, Degree of hydrolysis (per cent of total glycosidic bond in PGA). The amount of products was expressed as per cent of PGA added. The values were corrected for the amount of water for the hydrolysis of PGA. - GA; $-0,2 \mathrm{GA} ; \triangle-\triangle,{ }_{3} \mathrm{GA}$; $\Delta-\Delta, 4 \mathrm{GA} ; \square-\square, 5 \mathrm{GA} ; \mathbf{\square}-\mathbf{\square}$, higher oligogalacturonic acid.

\section{Table 2. Substrate specificity of polygalacturonase}

Reaction mixture contained $0.25 \%(\mathrm{w} / \mathrm{v})$ substrate and $4.2 \mathrm{PG}$ units of the enzyme in $2 \mathrm{ml}$ of $0 \cdot \mathrm{I}$ M-acetate buffer ( $\left.\mathrm{pH}_{4} \cdot \mathrm{I}\right)$. Enzyme assay was made at $30{ }^{\circ} \mathrm{C}$ with the semimicro hypoiodite method.

$\begin{array}{cc}\text { Substrate } & \begin{array}{c}\text { Aldehyde } \\ \text { group formed } \\ (\mu \mathrm{mol} / 5 \mathrm{~min})\end{array} \\ \text { 2GA } & 0.00 \\ \text { 3GA } & 0.00 \\ \text { 4GA } & 0.80 \\ \text { 5GA } & 1 \cdot 00 \\ \text { PGA } & 3.50\end{array}$

The specificity of the enzyme action was further studied by using oligogalacturonic acids as substrates. As shown in Table 2, the enzyme showed no activity towards $2 \mathrm{GA}$ and $3 \mathrm{GA}$. Oligomers longer than, and including, the tetramer seemed to be substrates of the enzyme. Products from $4 \mathrm{GA}$ and $5 \mathrm{GA}$ were then studied by paper chromatography. As shown in Fig. 6, 4GA produced $3 \mathrm{GA}$ and GA. In the case of $5 \mathrm{GA}$ hydrolysis, GA, $2 \mathrm{GA},{ }_{3} \mathrm{GA}$ and 4GA were formed with a molar ratio of approximately $1: 4: 4$ : I (Table 3 ). The result shows that $5 \mathrm{GA}$ can be split into either $4 \mathrm{GA}$ and $\mathrm{GA}$ or $3 \mathrm{GA}$ and $2 \mathrm{GA}$ and the splitting of $5 \mathrm{GA}$ into $3 \mathrm{GA}$ and $2 \mathrm{GA}$ was 4 times as fast as that into $4 \mathrm{GA}$ and $\mathrm{GA}$.

Because the enzyme could not hydrolyse $3 \mathrm{GA}$ but seemed to need at least three galacturonic acid units next to the glycosidic bond to split it, the inhibitory effect of $3 \mathrm{GA}$ on the 


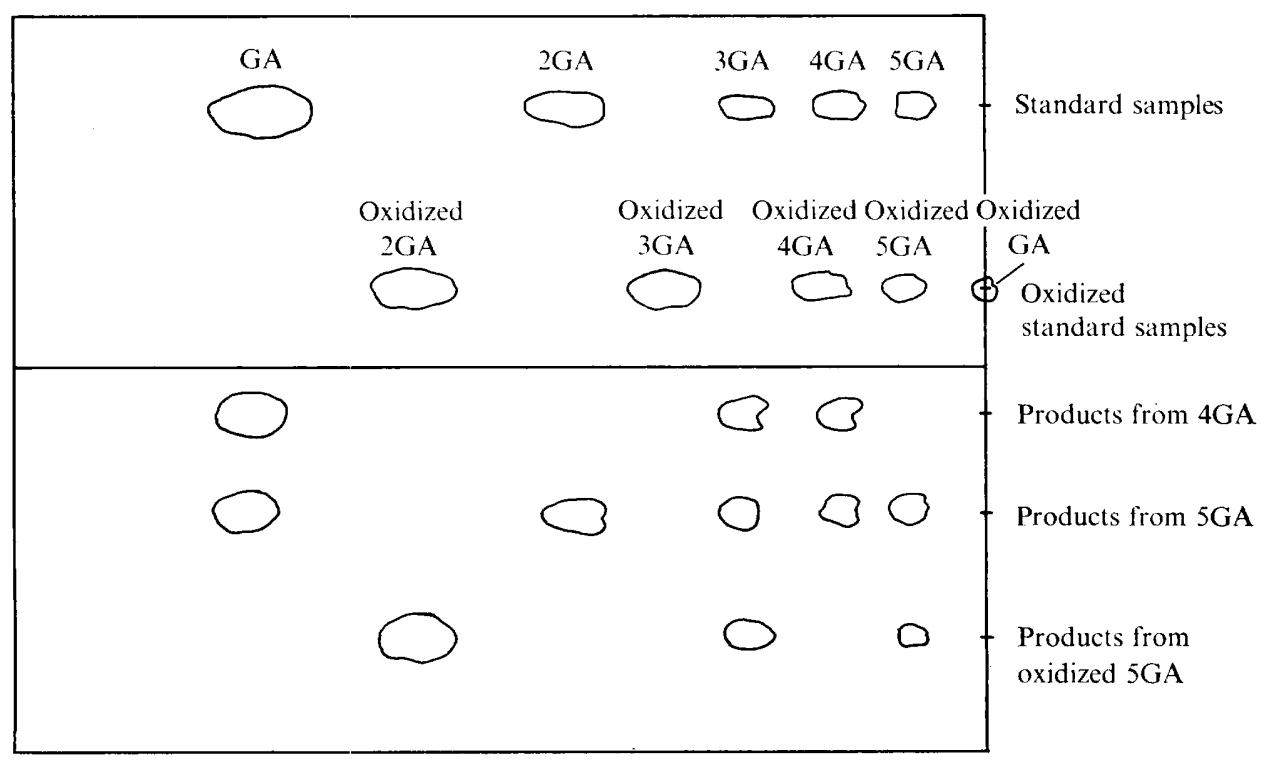

Fig. 6. Paper chromatogram of products from tetra-, penta- and oxidized pentagalacturonic acids.

Table 3. Products from penta- and oxidized pentagalacturonic acids

Reaction mixture contained $0.25 \%(\mathrm{w} / \mathrm{v})$ substrate and $25.2 \mathrm{PG}$ units of enzyme in $2 \mathrm{ml}$ of $0 . \mathrm{I} \mathrm{M}$ acetate buffer $(\mathrm{pH} 4 \cdot \mathrm{I})$. Enzyme assay was made for $5 \mathrm{~min}$ at $30^{\circ} \mathrm{C}$. Products were determined with carbazole reagent.

\begin{tabular}{|c|c|c|c|c|c|c|c|c|}
\hline \multirow{3}{*}{$\begin{array}{l}\text { Substrate } \\
5 \mathrm{GA}\end{array}$} & \multicolumn{8}{|c|}{ Product $(\mu \mathrm{mol})^{*}$} \\
\hline & GA & $\begin{array}{c}\text { Oxidized } \\
\text { GA }\end{array}$ & $2 \mathrm{GA}$ & $\begin{array}{c}\text { Oxidized } \\
2 \mathrm{GA}\end{array}$ & $3 \mathrm{GA}$ & $\begin{array}{c}\text { Oxidized } \\
3 \mathrm{GA}\end{array}$ & $\begin{array}{c}\text { 4GA and } \\
\text { oxidized } \\
4 \mathrm{GA}\end{array}$ & $\begin{array}{c}\text { 5GA and } \\
\text { oxidized } \\
\text { 5GA }\end{array}$ \\
\hline & 0.27 & - & $\mathbf{I} \cdot \mathbf{I} 3$ & 一 & $\mathrm{I} \cdot \mathrm{I} 3$ & 一 & 0.25 & $(3 \cdot 22)$ \\
\hline $\begin{array}{l}\text { Oxidized } \\
5 \mathrm{GA}\end{array}$ & 0 & 0 & 0 & $1 \cdot 10$ & $1 \cdot 30$ & 0 & $<0.05$ & $(3 \cdot 9)$ \\
\hline
\end{tabular}

* The amount of product was estimated on the basis of the molecular formula and the amount of GA unit found in the product.

enzyme action was studied. However, no inhibitory effect of $3 \mathrm{GA}$ on the hydrolysis of $4 \mathrm{GA}$ and PGA was observed.

The $K_{m}$ values for ${ }_{4} \mathrm{GA}, 5 \mathrm{GA}$ and PGA are presented in Table 4 . Because PGA is such a large molecule that many enzyme molecules can react on the same molecule of substrate, it is not adequate to use $K_{m}$ value. Therefore the calibration was made by using the concentration of galacturonic acid unit in the reaction mixture. The result indicates that the chain length of the substrate has a significant effect on the enzyme action.

From the results described above, we may conclude that the enzyme can split any glycosidic bond inside the third galacturonic acid unit from one of the terminals of PGA. To determine on which terminal (reducing or non-reducing terminal) the enzyme needs three galacturonic acid units, the terminal aldehyde group of oligomers was oxidized to the carboxylic acid group. The hydrolysis of oxidized 4GA did not occur at all, while oxidized 5GA did. Quantitative analysis of the products was made by paper chromatography in 
Table 4. $K_{m}$ and $V_{\max }$ values for oligo- and polygalacturonic acids

Reaction mixture contained the substrate indicated in the table and 6.3 PG units of enzyme in $2 \mathrm{ml}$ of $0 . \mathrm{I}$ M-acetate buffer ( $\left.\mathrm{pH} \mathrm{I}_{4}\right)$. Substrate concentration was $0.25 \%, 0.20 \%, 0.15 \%$ and $0.10 \%$, respectively. Enzyme assay was made at $30^{\circ} \mathrm{C}$ with the semimicro hypoiodite method.

$\begin{array}{cccc}\text { Substrate } & \overbrace{\mathrm{g} / \mathrm{l}} & { }^{\mathrm{M}} & \\ \text { 4GA } & 8 \cdot 4 & 0.0084 & 0.46 \\ 5 \mathrm{GA} & 4 \cdot 8 & 0.0048 & 0.50 \\ \text { PGA } & 2 \cdot \mathrm{I} & - & 0.9 \mathrm{I}\end{array}$

streaks. A part of the paper was sprayed with mixed reagent of bromocresol green and bromophenol blue. Besides the $5 \mathrm{GA}$, two spots corresponding to oxidized $2 \mathrm{GA}$ and $3 \mathrm{GA}$ were detected. Areas corresponding to each of the oxidized and non-oxidized oligomers and GA were eluted with $0.2 \%(\mathrm{w} / \mathrm{v})$ ammonium oxalate, and the amount of galacturonic acid residue and aldehyde group were determined separately. As shown in Table 3, major products were $3 \mathrm{GA}$ and oxidized $2 \mathrm{GA}$ with the molar ratio of $\mathrm{I}: \mathrm{I}$. The molar ratio of nonoxidized GA residue in these products was close to $\mathrm{I}: 3$. Aldehyde group in $3 \mathrm{GA}$ and oxidized $2 \mathrm{GA}$ fractions was also determined. Aldehyde $(0.96 \mu \mathrm{mol})$ was found in I $\mu \mathrm{mol}$ of $3 \mathrm{GA}$, while no aldehyde group was found in oxidized $2 \mathrm{GA}$ fraction. These results clearly show the cleavage of oxidized $5 \mathrm{GA}$ into oxidized $2 \mathrm{GA}$ and $3 \mathrm{GA}$. The rate of cleavage of oxidized $5 \mathrm{GA}$ was comparable to that of non-oxidized 5GA (Table 3 ).

\section{DISCUSSION}

Substrate specificity of the polygalacturonase purified from a strain of Acrocylindrium is restricted to those oligogalacturonic acids which have four or more galacturonic acid units. Tetragalacturonic acid was hydrolysed to $3 \mathrm{GA}$ and $\mathrm{GA}$, while $5 \mathrm{GA}$ was hydrolysed to either $3 \mathrm{GA}$ and $2 \mathrm{GA}$ or $4 \mathrm{GA}$ and $\mathrm{GA}$. The rate of hydrolysis of $4 \mathrm{GA}$, the smallest substrate, was one-fourth of that of PGA. These results show that the enzyme can hydrolyse any glycosidic bond which has more than three galacturonic acid residues next to it.

In order to determine on which side of the glycosidic bond to be hydrolysed the oligomer needs three galacturonic acid units, oxidized 5GA which has a carboxylic group instead of an aldehyde group at a terminal, was used. The hydrolysed products of oxidized $5 \mathrm{GA}$ were exclusively $3 \mathrm{GA}$ and oxidized $2 \mathrm{GA}$, showing the requirement of three galacturonic acid units at the non-reducing end of the substrate for the enzyme action. The rate of hydrolysis of oxidized $5 \mathrm{GA}$ was about $70 \%$ of that of $5 \mathrm{GA}$. This suggests the same manner of cleavage in both cases.

The hydrolysis of oxidized $4 \mathrm{GA}$ and that of oxidized $5 \mathrm{GA}$ into $4 \mathrm{GA}$ and oxidized $\mathrm{GA}$ were not observed. This must have been due to the change by oxidation of a galacturonic acid unit adjacent to the bond to be hydrolysed. If the enzyme had the ability to release GA from the non-reducing end of an oligomer, GA formation would have been observed even with oxidized oligomers.

As shown in Table $3,5 \mathrm{GA}$ was preferentially hydrolysed into $3 \mathrm{GA}$ and $2 \mathrm{GA}$ and the rate of splitting into $4 \mathrm{GA}$ and $\mathrm{GA}$ was about one-fourth of that into $3 \mathrm{GA}$ and $2 \mathrm{GA}$. The fact that the rate of splitting of $4 \mathrm{GA}$ into $3 \mathrm{GA}$ and $\mathrm{GA}$ was almost comparable to the rate of hydrolysis of $5 \mathrm{GA}$, suggests that the enzyme should be able to hydrolyse $5 \mathrm{GA}$ into $4 \mathrm{GA}$ and $\mathrm{GA}$ at a comparable rate. A possible explanation for the anomaly is that the longer 
galacturonic acid chain on the non-reducing side would lower the rate of the hydrolysis. Although the possibility cannot fully be excluded, it is unlikely, because PGA showed the smallest $K_{m}$ value and largest $V_{\max }$ among substrates tested even when the estimation was made per galacturonic acid unit. If a larger chain on the non-reducing side inhibits enzyme action, the rate of hydrolysis of PGA would have been slower than that of oligomers. Another possible explanation for the anomaly is as follows: if the enzyme has a higher affinity for the second bond from the reducing terminal than for the first bond, the hydrolysis of the first bond would be competitively inhibited by the second bond which is located about $5 \mathrm{~nm}$ away. Although we do not know the $K_{m}$ value for the first bond of $5 \mathrm{GA}$, the $K_{m}$ value for the first bond of ${ }_{4} \mathrm{GA}$ was about twice as large as that for the hydrolysis of $5 \mathrm{GA}$ in which the 2 GA-3GA split is predominant. However, such a difference in $K_{m}$ values does not seem enough to account for the preferential hydrolysis of $5 \mathrm{GA}$ into $3 \mathrm{GA}$ and $2 \mathrm{GA}$.

The enzyme showed the smallest $K_{m}$ value for PGA. Trigalacturonic acid showed no inhibitory effect for the hydrolysis of $4 \mathrm{GA}$ and PGA, which means that $3 \mathrm{GA}$ shows no significant affinity towards the enzyme. These results suggest that although the enzyme seems to need at least 3 galacturonic acid units near its active centre for its action, a longer galacturonic acid chain on the side of the reducing terminal contributes to higher affinity of substrates for the enzyme.

\section{REFERENCES}

Demain, A. L. \& Phaff, H. J. (1957). Recent advances in the enzymatic hydrolysis of pectic substances. Wallerstein Laboratories Communications 20, I I9-I 40.

Dische, Z. (1947). A new specific color reaction of Hexuronic acids. Journal of Biological Chemistry 167, I $89-198$.

ENDo, A. (1964a). Studies on pectolytic enzymes of molds: Part VIII. Purification and properties of endopolygalacturonase I. Agricultural and Biological Chemistry 28, 535-542.

ENDo, A. (1964b). Studies on pectolytic enzymes of molds: Part XI. Purification and properties of exopolygalacturonase. Agricultural and Biological Chemistry 28, 639-645.

Hatanaka, C. (1967). Micro-iodometry of aldose. Journal of the Agricultural Chemical Society of Japan 4I, $448-453$.

Hatanaka, C. \& Ozawa, J. (I 966). Enzymic degradation of pectic acid. Journal of the Agricultural Chemical Society of Japan 40, 98-105.

JANSEN, E. F. \& MACDONNELL, L. R. (I945). Influence of methoxyl content of pectic substances on the action of polygalacturonase. Archives of Biochemistry 8, 97-112.

Koller, A. \& Neukom, H. ( 1969 ). Untersuchungen über den Abbaumechanismus einer gereinigten Polygalacturonase aus Aspergillus niger. European Journal of Biochemistry 7, 485-489.

Lowry, O. H., Rosebrough, N. J., Farr, A. L. \& Randall, R. J. (195I). Protein measurement with the Folin phenol reagent. Journal of Biological Chemistry 193, 265-275.

Matsumura, T. (1969). Chemistry of constituents of polysaccharides. In Tatō seikagaku, vol. I, p. 53. Edited by A. Suzuki, T. Matsumura and I. Yamashina. Tokyo: Kyoritsu Press.

Mill, P. J. (1966a). The pectic enzymes of Aspergillus niger: a mercury-activated exopolygalacturonase. Biochemical Journal 99, 557-561.

Mill, P. J. (I $966 b$ ). The pectic enzymes of Aspergillus niger: a second exopolygalacturonase. Biochemical Journal 99, 562--565.

Mill, P. J. \& Tuttobello, R. (I96I). The pectic enzymes of Aspergillus niger: 2. Endopolygalacturonase. Biochemical Journal 79, 57-64.

NAsuno, S. \& STARr, M. P. (I966). Polygalacturonase of Erwinia carotovora. Journal of Biological Chemistry 24I, 5298-5306.

PÁskoví, J. \& Munk, V. (I960). A combined detecting reagent for the identification of organic acids on paper chromatograms. Journal of Chromatography 4, 24I-243.

Patel, D. S. \& Phaff, H. J. (I959). On the mechanism of action of yeast endo-polygalacturonase on oligogalacturonides and their reduced and oxidized derivatives. Journal of Biological Chemistry 234, $237^{-24}$ I. 
Patel, D. S. \& Phaff, H. J. (1960). Properties of purified tomato polygalacturonase. Food Research 25, 47-57.

PhafF, H. J. \& LuH, B. S. (1952). The preparation of pure di- and trigalacturonic acids. Archives of Biochemistry and Biophysics 36, 23I-232.

Preiss, J. \& Ashwell, G. (1963). Polygalacturonic acid metabolism in bacteria: II. Formation and metabolism of 3-deoxy-D-glycero-2,5-hexodiulosonic acid. Journal of Biological Chemistry 238, 1577-I 583.

RoBoz, E., BarRatT, R. W. \& TATUM, E. L. (1952). Breakdown of pectic substances by a new enzyme from Neurospora. Journal of Biological Chemistry 195, 459-47I.

UCHINo, F., Kurono, Y. \& DoI, S. (1966). Crystallization of an endopolygalacturonase from Acrocylindrium sp. Agricultural and Biological Chemistry 30, 1066-1068. 